\title{
Fostering Problem-based Learning Competence through Teaching the Generalization of Practical Problems on the Topic of Exponential and Logarithmic Functions
}

\author{
Ngoc-Giang Nguyen ${ }^{1, *}$, Huyen-Trang Pham ${ }^{2}$, Thi-Ngoc Tham Nguyen ${ }^{3}$ \\ ${ }^{1}$ Faculty of Economic Mathematics, Banking University of Ho Chi Minh City, Vietnam \\ ${ }^{2}$ Faculty of Primary Education, Hanoi Pedagogical University 2, Vietnam \\ ${ }^{3}$ Ho Chi Minh City, 28, Vietnam
}

Received December 24, 2020; Revised January 24, 2021; Accepted March 1, 2021

\section{Cite This Paper in the following Citation Styles}

(a): [1] Ngoc-Giang Nguyen, Huyen-Trang Pham, Thi-Ngoc Tham Nguyen, "Fostering Problem-based Learning Competence through Teaching the Generalization of Practical Problems on the Topic of Exponential and Logarithmic Functions," Universal Journal of Educational Research, Vol. 9, No. 3, pp. 423-440, 2021. DOI: 10.13189/ujer.2021.090302.

(b): Ngoc-Giang Nguyen, Huyen-Trang Pham, Thi-Ngoc Tham Nguyen (2021). Fostering Problem-based Learning Competence through Teaching the Generalization of Practical Problems on the Topic of Exponential and Logarithmic Functions. Universal Journal of Educational Research, 9(3), 423-440. DOI: 10.13189/ujer.2021.090302.

Copyright $\odot 2021$ by authors, all rights reserved. Authors agree that this article remains permanently open access under the terms of the Creative Commons Attribution License 4.0 International License

\begin{abstract}
Problem-based learning competence is one of the most important competencies of mathematical competence. Many researchers believe that this capacity is a factor that directly affects the development of students' competencies and qualities. Among the components of problem-based learning competencies, the generalization of the problem is one of the key factors. Especially generalization of problems about exponential functions and logarithmic functions is still an open issue, which is rarely interested in research. Our research is carried out to identify and analyze factors of problem-based learning competence through generalizing the actual problems on the topic of exponential and logarithmic functions in Vietnam. The questionnaire survey method with 47 high school teachers in Ho Chi Minh City, Vietnam, shows that $10.64 \%$ of teachers think that the teaching method of problem-based learning competence is of little importance; $25.53 \%$ think it is important and $63.83 \%$ think it is very important. We conducted experiments with 89 students and processed analytical data using SPSS software. From the results of qualitative and quantitative analysis, students showed interest and fascination with the generalized teaching method of the actual problem. The test results showed that the experimental class had a much higher score than the control class. The research also provides a table comparing the differences between problem-solving
\end{abstract}

and discovery teaching with teaching to develop problem-based learning competence; the process of teaching generalizations as well as examples illustrating practical problems on the topic of exponents and logarithmic functions. Research results also show that students are excited, proactively discover and learn from real-life problems more than before and do more practical issues. The findings from the research have important implications in fostering problem-based learning competence through generalizing practical problems on the topic of exponents and logarithms for students.

Keywords Teaching Problem-based Learning Competence, Practical Math, Exponential Functions, Logarithmic Functions

\section{Introduction}

In the world, there are many pieces of research on competency as well as teaching towards capacity development, especially problem-solving capacity in mathematics and other subjects.

Deborah (2009) in the Doctoral Dissertation " $A$ problem-posing intervention in the development of 
through Teaching the Generalization of Practical Problems on the Topic of Exponential and Logarithmic Functions

problem-solving competence of underachieving, middle-year students", mentioned issues related to the competence to solve problems of high school students with average academic performance. The author argues that participation in questioning activities can facilitate their math learning. Besides, participating in these activities helps them improve their ability to solve problems significantly. [1]

Kretzschmar \& Suß (2015) presented the problem-solving concept and the meaning of the problem-solving concept in the article "A study on the training of complex problem-solving competence". The study also mentioned the process of applying problem-solving knowledge specifically. [2]

Syaifuddin (2017) conducted the study "Increasing Problem Solving Competence through Problem-Based Learning Model and Scientific Approach" which was designed based on the classroom activities of the 8th-grade students of Muhammadiyah Middle School in Batu Malang. The purpose of the research is to analyze the level of students' learning activities and to improve problem-solving capabilities. Data sources used for analysis are collected by the author by observing students' learning activities in class and performing tests that measure their ability in math problems. Research results show that the practice of teaching math with problem detection and solving teaching methods can enhance learning activities and math problem-solving abilities for students. [3]

In Vietnam, there are also many studies on problem-based learning competence as well as the topic of exponent and logarithmic functions. Master thesis "Assessing students' ability to solve problems in teaching the chapter" Laws of conservation "in the book Physics 10 " by Hoang Thi Thu Ha (2015) affirms that we can evaluate capacity to solve problems in the form of multiple-choice tests which are logically and scientifically designed. The author gave comments as well as how to evaluate problem-solving capacity through teaching the chapter "Conservation laws" in the book Physics 10. [4]

In the Doctoral thesis "Teaching mathematics in high schools towards developing the capacity to solve practical problems through the exploitation and use of real situations", author Ha Xuan Thanh (2017 ) clarified the concept of practical problem-solving capacity and related concepts. The thesis also has contributions such as: Proposing ways to exploit and build problems containing practical situations; Giving directions and teaching methods using real-world problems to contribute to the development of the capacity to solve practical problems in teaching Mathematics. Through the thesis, the author shows the necessity and role of Mathematics in life; helps students connect Mathematics to life; creates excitement for students while learning Math; at the same time, creates a resource about math problems containing practical situations for teachers and students. [5]
Nguyen Duong Hoang (2019) believes that the curriculum towards competency-oriented is a popular trend and widely applied in many countries around the world. One of the necessary skills to develop in learners is computation. Realizing that, in the article "Developing computational capacity for students in teaching the chapter" Exponentiation functions, exponential functions, and logarithmic functions "(Calculus grade 12)", the author has determined expressions of computational capacity in the Mathematics curriculum in the chapter Exponentiation functions, exponential functions, and logarithmic functions. From that, the author proposes four measures to develop students' computing capacity in teaching this chapter to contribute to improving the teaching quality of Mathematics in high schools. [6]

Although there are many studies on problem-solving capacity, on the topic of exponent and logarithmic functions, the topic of fostering problem-based learning competence through teaching practical problems on the topic of exponential and logarithmic functions at high school is quite new, no one has studied in Vietnam. Therefore, our work will focus on this topic.

In this paper, we are going to answer four questions:

1. Compare problem detection and solving teaching methods with teaching towards developing problem-based learning competence?

2. Is there a process of teaching generalizing practical problems on the topic of exponents and logarithms?

3. Do we give some illustrative examples of problem-based learning competence through teaching about generalizing the real problem on the topic of exponents and logarithmic functions?

4. To prove the effectiveness of teaching about generalizing the real problem on the topic of exponents and logarithmic functions?

\section{Content}

\subsection{Competence}

Competence is a concept that many people are interested in researching. This is a concept with many different definitions, inconsistent with each other, but extremely important in life. Researchers have outlined the definition of competency from their perspectives, below are some definitions of competency from different perspectives of researchers:

Competency is the individual's ability to work whose performance parameters meet the requirements of the business, or organization. Because of this good response, the business or organization wants to hire him or her [7]. It is a combination of available or learned abilities, skills as well as students' readiness to solve emerging problems and act responsibly, critically to come to solutions [8]. Competence is the ability to effectively respond to 
complex requirements in a particular context [9]. Competence is the ability to perform work based on mobilizing and using a combination of resources to effectively solve life situations, thereby reaping progress and success in life. [10]. Competency is the combination of a series of knowledge, abilities, skills, experiences, and behaviors that results in effective personal activities. Competency is measurable and can be developed through training. It can also be subdivided into smaller criteria [11].

In Vietnam, there are many authors with different points of view when studying the concept of competency, especially in the field of education. Competency is a characteristic of an individual demonstrating a degree of proficiency, ie being able to perform skillfully and with certainty, one or several types of activities [12]. Competency is a psychological and physiological quality that enables people to complete a certain type of activity with high quality [13]. Competency is a combination of psychological characteristics of a person (also known as a combination of psychological attributes of a personality). This feature combination operates for a certain purpose to produce the result of a certain activity [14]. Competency is a personal attribute that allows an individual to successfully perform certain activities and achieve the desired results under specific conditions [15]. Competency is a personal attribute formed and developed by existing qualities and the process of learning and training allows people to successfully perform a certain type of activity and achieve desired results under specific conditions.[16]. Competence is the mobilization of knowledge, skills and other personal attributes such as interest, belief, will ... to perform a type of work in a certain context [17]. Competency is a personal attribute formed and developed by existing qualities and the process of learning and training allows people to mobilize a combination of knowledge, skills, and other personal attributes such as interest, belief, will, ... successfully perform a certain type of activity and achieve desired results under specific conditions [18].

From the above things, we recognize that the definitions of competence refer to the ability to successfully perform activities, the knowledge, skills and personal attributes. Some definitions do not refer to the certain context.

Based on the views of many authors given above, we conceive as follows: "Competence is the ability to successfully perform activities in a certain context thanks to the mobilization and synthesis of knowledge, skills, and other personal attributes such as excitement, belief, will ... Individual competence is assessed by the method and ability of that individual to deal with life problems. "

\subsection{Mathematical Competence}

Mathematical competence has been researched by scientists since the beginning of the twentieth century and one of the initiators of this concept is the French mathematician H. Poincaré. This mathematician believes that mathematical competency has a specificity (thinking and reasoning, posing and solving problem, etc) and that the most important component is mathematical intuition. According to psychologists, mathematical competencies have three forms: arithmetic competency, algebraic competency, and geometric competency. In the last century, A.E. Camenron, L.V. Commerel, H. Thomas, E.L. Thorndike, V. Haecker, and Th. Ziehen was interested in doing research and tried to come up with the composition of the mathematical competency. The most remarkable and still receiving much attention is the work of psychologist E.L. Thorndike. Besides, many psychologists and mathematicians published many studies on mathematical competencies. [19]

The concept of mathematical competency has been studied for a long time. However, the 2002 article on Mathematical Competencies and the Learning of Mathematics: The Danish KOM Project by Mogens Niss marked a strong development of research on this topic. Since that time, Mogens Niss has been considered by many people in the education field as an expert in mathematical competency. Also according to Mogens Niss, "Mathematical competence means the ability to understand, judge, do and use mathematics in many mathematical contexts and situations inside and outside mathematics". A prerequisite for mathematical competency is a lot of practical knowledge and technical skills, which are necessary, but certainly not enough, just as vocabulary, spelling, and grammar are necessary but not sufficient prerequisites for literacy. He was also the first to elaborate on the eight elements of mathematical competency, namely, mathematical thinking, mathematical reasoning, problem discovery and problem-solving, mathematical communication, mathematical representation, modeling mathematically, using mathematical symbols and formulas, and using aids and tools (IT included). Mogens Niss said that eight types of mathematical competencies form two groups. The first group of competencies is to ask and answer mathematical questions including mathematical thinking, problem discovery and problem-solving, mathematical modeling (analysis and model building) as well as mathematical reasoning. The second group of mathematical competencies is the processing and management of languages and mathematical tools, including mathematical representation, using mathematical formulas and symbols, communicating mathematics, using tools and support facilities (including information technology) [20]. Mathematical competence is the ability to be ready to act to adapt to mathematical challenges in a defined context or situation [21].

It can be said that mathematical competency is not the ability to learn and master mathematical knowledge, but it 
aims at students' understanding, application, and development of skills, analytical, reasoning, and reasoning abilities, generalizing and discovering mathematical knowledge hidden within certain situations and events. Both competency and mathematical competency are concepts that are of special interest in the present period. Applying mathematics to practical situations is one of the key factors in capacity development-oriented teaching. Students will find that Mathematics is life-bound and truly beneficial.

\subsection{Problem-based Learning Competence}

Problem-based learning competence is one of the important core competencies needed by learners; It is also a concept with many different interpretations and representations. Problem-based learning competence is the ability of an individual to recognize, understand, and resolve problem situations without a clear resolution. There, the individual is willing to engage in similar situations to achieve his or her potential as an active and constructive citizen [22]. Problem-solving capacity is a flexible and organized combination of individual knowledge, skills, attitudes, emotions, ... to meet complex requirements in a defined context [23]. Mathematical problem-solving capacity is defined as the ability to solve real-world problems and transform problem-solving solutions through perception and technology, and the ability to solve problems using how to apply cognitive skills such as reasoning and logical thinking. Problem-solving is done in two phases, problem representation and problem-solving. [24]

In Vietnam, there are also many authors researching problem-based learning competence. Problem-solving capacity is the ability to effectively use an individual's cognitive processes, motivations, and emotions to solve problem situations where conventional solutions do not immediately resolve [25 ]. Problem-solving and creativity capacity is the individual's ability to effectively use cognitive processes, actions and attitudes, motives, and emotions to analyze, propose solutions, choose solutions, and perform solving learning and practical situations, problems in which no normal processes, procedures, or solutions are available; at the same time, to evaluate problem-solving solutions to adjust and apply flexibly in new circumstances and tasks. Problem-based learning competence demonstrates the individual's ability to think about problem situations, find and implement solutions to those problems when working in groups or alone [18].

From the above points of view, we agree with the point of view of the General Education Program in Vietnam (2018), it is possible to understand that problem-based learning competence is the ability of individuals to effectively use knowledge, skills, attitudes, ... to recognize, detect and resolve problem situations in a given context, in which there may or may not be a common process, procedure or solution.

\subsection{Teaching According to the Orientation of Developing Problem-based Learning Competence}

Teaching Mathematics contributes to forming and developing the quality and competence of students. Specifically, Mathematics contributes to the formation and development of specific and core competencies such as computing capacity, language capacity, communication and cooperation capacity, mathematical modeling capacity, problem-solving capacity, and creativity, ... Each capacity is a teaching method oriented to individual capacity development. And in this paper, we focus on teaching methods towards the development of problem-based learning competence.

Teaching methods towards the development of problem-based learning competence focus on developing the necessary competencies so that learners can apply knowledge to practical situations to prepare and develop the ability to detect and solve problems in life and work.

Problem detection and solving teaching is a method of teaching by problem detection and problem-solving methods to find new knowledge. Here students can or may not do it while doing the problem detection and solving activity. That is, the students' academic performance can be effective, or less effective, or not. Meanwhile, teaching that develops the ability of problem-based learning competence is teaching in which we make sure that students, after learning, will solve some similar problems effectively.

To clarify the above difference, we give our views and evaluation on teaching in the direction of developing problem-based learning competence; At the same time, we compare some of its basic characteristics with problem-solving and discovery teaching methods. We refer to the documents [26], [27], [28], [29] and give the following comparison table: 
Table 1. Comparison of problem detection and solving teaching methods with teaching towards developing problem-based learning competence

\begin{tabular}{|c|c|c|}
\hline Characteristics & Problem-solving and discovery teaching & $\begin{array}{l}\text { Teaching according to the orientation of developing } \\
\text { the problem-based learning competence }\end{array}$ \\
\hline Input conditions & $\begin{array}{l}\text { Students acquire knowledge and develop the necessary } \\
\text { skills in problem detection and solving. }\end{array}$ & $\begin{array}{l}\text { Students can detect and solve problems, know and } \\
\text { perform the manipulations and skills of this competency. }\end{array}$ \\
\hline Output result & $\begin{array}{l}\text { Forming new knowledge in the process of teaching } \\
\text { problem detection and solving. Helping students master } \\
\text { knowledge through problem-solving and discovery } \\
\text { activities. }\end{array}$ & $\begin{array}{l}\text { - Mastering knowledge through teaching activities } \\
\text { oriented to develop problem-based learning competence. } \\
\text { - Students know how to apply knowledge to real } \\
\text { problems. }\end{array}$ \\
\hline $\begin{array}{l}\text { Educational } \\
\text { goals }\end{array}$ & $\begin{array}{l}\text { - The teaching objectives described are not very detailed } \\
\text { and need not be observed or evaluated. } \\
\text { - Helping students to acquire new knowledge through the } \\
\text { results of the problem-solving process in an active and } \\
\text { exploratory manner in the problem-solving process. } \\
\text { - Help students begin to get acquainted, develop skills such } \\
\text { as problem detection and presentation, finding ways to } \\
\text { solve problems, examining and evaluating results, and } \\
\text { problem-solving methods. }\end{array}$ & $\begin{array}{l}\text { - Learning results should be described in detail, } \\
\text { observable, assessed, and able to show the progress of } \\
\text { students. } \\
\text { - To develop learners' problem-based learning } \\
\text { competence to ensure the output quality of teaching. } \\
\text { - Focusing on the ability to apply knowledge and } \\
\text { capacity in practical situations to prepare people for the } \\
\text { capacity to solve situations and problems of life and } \\
\text { work. }\end{array}$ \\
\hline $\begin{array}{l}\text { Educational } \\
\text { content }\end{array}$ & $\begin{array}{l}\text { - Teachers base on the content of knowledge that needs to } \\
\text { be conveyed to create problem situations and create } \\
\text { excitement for students to actively and gradually discover } \\
\text { new knowledge in the problem-solving process. } \\
\text { - Content is specified in the program. }\end{array}$ & $\begin{array}{l}\text { - Teachers select suitable content, associated with } \\
\text { practical situations to achieve the specified outputs } \\
\text { (developing problem-based learning competence). } \\
\text { - The content is not specified in detail, only the main } \\
\text { content is specified. }\end{array}$ \\
\hline $\begin{array}{l}\text { Teaching } \\
\text { methods }\end{array}$ & $\begin{array}{l}\text { - Take knowledge standards as the basis for curriculum } \\
\text { design and teaching content. } \\
\text { - Teachers (or with students) create problem situations, } \\
\text { organize and control students to discover, present } \\
\text { problems, and solve problems so that students acquire } \\
\text { knowledge, skills, and develop thinking development. } \\
\text { - Students are placed in a problem-provoking situation } \\
\text { rather than passively informed knowledge in a form } \\
\text { available. } \\
\text { - Students do not fully actively mobilize their knowledge } \\
\text { and ability to detect and solve problems. }\end{array}$ & $\begin{array}{l}\text { - Taking capacity as a reference basis for organizing, } \\
\text { designing programs, and learning content. } \\
\text { - Teachers are mainly the organizers, supporting students } \\
\text { to autonomously and actively perform tasks of learning } \\
\text { and acquiring knowledge; the learner is the center. } \\
\text { - Teachers pay close attention to each student to help } \\
\text { them explore, discover, master, and apply knowledge to } \\
\text { solve real-life problems and situations. } \\
\text { - Focusing on the development of communication skills, } \\
\text { problem-solving ...; using a combination of active } \\
\text { teaching perspectives, methods, and techniques; } \\
\text { teaching methods of experiment and practice. }\end{array}$ \\
\hline Teaching mode & $\begin{array}{l}\text { Mainly teaching in theory and depending on the } \\
\text { independence of students, there are the following main } \\
\text { forms of teaching: self-study learners, cooperative } \\
\text { learners, asking and answering questions between teachers } \\
\text { and students; teacher presentations on problem detection } \\
\text { and resolution. }\end{array}$ & $\begin{array}{l}\text { Organizing diverse forms of learning; paying attention to } \\
\text { social activities, extracurricular activities, scientific } \\
\text { research, and creative experiences; promoting the } \\
\text { application of information technology and } \\
\text { communication in teaching and learning. }\end{array}$ \\
\hline $\begin{array}{l}\text { Evaluating } \\
\text { students' } \\
\text { learning results }\end{array}$ & $\begin{array}{l}\text { - Evaluation criteria are based on learned knowledge that } \\
\text { students have memorized and demonstrated. } \\
\text { - Evaluating the knowledge that students construct, } \\
\text { comprehend, and apply new knowledge. }\end{array}$ & $\begin{array}{l}\text { Evaluation criteria are based on the output capacity, the } \\
\text { continual progress in the student's learning process, and } \\
\text { focus on the applicability in practical situations. }\end{array}$ \\
\hline $\begin{array}{l}\text { Teaching } \\
\text { environment }\end{array}$ & $\begin{array}{l}\text { Creating problem-solving situations, directing students to } \\
\text { discover problems, be self-aware, positive, and creative to } \\
\text { solve problems; encouraging students to work together and } \\
\text { interact with teachers to solve problems and build } \\
\text { knowledge. }\end{array}$ & $\begin{array}{l}\text { Facilitating positive interactions between students, } \\
\text { between students and teachers; motivating and helping } \\
\text { students to realize their problem-based learning } \\
\text { competence through observation, communication, } \\
\text { exploration, discovery, and creation. }\end{array}$ \\
\hline learning method & $\begin{array}{l}\text { Students learn and perform under the guidance and } \\
\text { suggestion of teachers and it depends on the student's } \\
\text { independence and interest in learning. }\end{array}$ & $\begin{array}{l}\text { Students can do learning activities on their own, group } \\
\text { study, and practice in activities and through activities. } \\
\text { Teachers provide support only when needed. }\end{array}$ \\
\hline $\begin{array}{l}\text { Advantages and } \\
\text { disadvantages }\end{array}$ & $\begin{array}{l}\text { - Advantages: good effect in activating students' cognitive } \\
\text { activities, increasing the interaction, dynamism, and } \\
\text { creativity between teachers and students in teaching, ... } \\
\text { - Disadvantages: time-consuming, requires the teacher to } \\
\text { have professional qualifications, a lot of dedication and } \\
\text { creativity, and must clearly define the conditions for } \\
\text { effective problem-solving and discovery teaching. }\end{array}$ & $\begin{array}{l}\text { - Advantages: good quality management according to } \\
\text { specified outputs, emphasizing students' problem-based } \\
\text { learning competence. } \\
\text { - Disadvantages: it depends on the implementation } \\
\text { process; if applying a bias to focus on competencies, not } \\
\text { paying attention to teaching content, will lead to a lack of } \\
\text { basic knowledge and affect the systematization of } \\
\text { knowledge. }\end{array}$ \\
\hline
\end{tabular}




\subsection{The Purpose of Fostering Problem-based Learning Competence through Teaching the Generalization of Practical Problems with Exponential Functions and Logarithmic Functions}

The purpose of fostering problem-based learning competence through teaching the topic of exponents and logarithms is to help students establish and formulate general formulas. Each general formula is a mathematical solution to problems of the same type (cell division; compound interest problem; continuous compound interest rate problem; capital contribution problem). Through forming the general formula, students will be trained and fostered in reasoning, logical thinking, creative thinking as well as problem-based learning competence. Finally, students know how to apply formulas for real problems to form their problem-solving skills.

\subsection{Scientific Basis of Fostering Problem-based Learning Competence through Teaching the Generalization of Practical Problems on the Topic of Exponential Functions and Logarithmic Functions}

Since the Pythagorean era, the question of whether mathematics comes from reality has been raised. Up to now, over thousands of years of history, the above question has always been a topical question that is concerned by many people [30]. The most important task of teaching mathematics in high schools is to teach how to set up equations to solve quiz problems. The quiz problems including real problems [31]. First, teachers tend to think that knowledge of mathematics comes from real problems. Second, mathematics is a useful tool to help solve real problems effectively. Third, students can really have difficulties solving real-life problems in that mathematics is an abstract and coherent knowledge system, while real problems are often complex and trouble [32].

Thus, setting up several general formulas according to the teaching process-oriented to develop problem-based learning competence on the topic of exponential functions, logarithmic functions in particular and practical mathematics, in general, is always the topic of much attention and also a difficult topic in teaching. In our opinion, one of the main reasons students have difficulty solving real problems is that they do not have a common process, and knowledge of real math is diverse and rich.

\subsection{Teaching Process of Generalizing Practical Problems on the Topic of Exponents and Logarithms}

Through research on the topic of exponential functions and logarithmic functions, we offer a teaching process generalizing the real problem according to the development orientation of problem-based learning competence in figure 1.

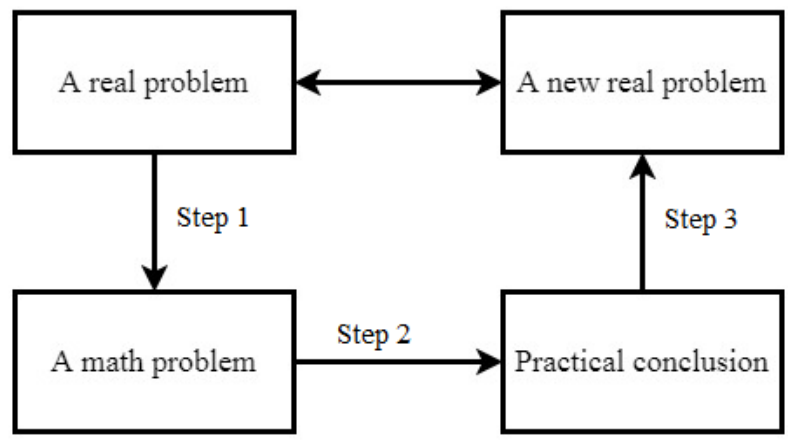

Figure 1. Real problem-solving process

Here we would like to detail each step in the process above:

Step 1: Convert from a real problem to a math problem

+ Find out the problem: reading the problem, summarizing the problem (determining the condition factor, information, conclusion requirements of the problem).

+ Select appropriate equations, exponential formulas, logarithmic functions to represent the conditions and facts of the problem.

+ Making appropriate mathematical models to solve real problems.

Step 2: Solve math problems

+ Find plans and algorithms to solve the modeled problem.

+ Solve the modeled problem that was set up in step 1 by using mathematical tools, reasoning, and mathematical inference about exponential functions, logarithmic functions.

+ Convert math problems to actual conclusions. Make conclusions for the actual problem and adjust (if any).

Step 3: Expand and exploit the actual problem

Generalize, similarize, find the inverse problem for the original real problem, find other solutions, or you can apply this problem to solve other real problems, ...

\subsection{An Illustrative Example of Problem-based Learning Competence through Teaching about Generalizing the Real Problem on the Topic of Exponents and Logarithmic Functions}

Example 1. If we start with a unicellular yeast cell under favorable growth conditions, it will split into two identical "daughter cells" within one hour. Next, after an hour, each of these daughter cells will divide into two identical cells.

a). Set up the formula to represent the number of cells after $n$ hours. Then find the number of identical daughter cells after 24 hours. 
b). When will we have 1024 "daughter cells" identical to the original mother cell. [33]

We guide students to solve the above example according to the teaching process of generalizing the actual problem on the topic of exponents and logarithmic functions oriented to the development competence of problem-based learning in table 2 as follows:

Table 2. Teaching the generalization of the yeast cell problem

\begin{tabular}{|c|c|}
\hline Teacher & Students \\
\hline \multicolumn{2}{|c|}{ Step 1: Convert from an actual problem to a math problem } \\
\hline $\begin{array}{l}\text { What data does the topic give? What are the } \\
\text { requirements and goals to look for? Are there any } \\
\text { conditions? }\end{array}$ & $\begin{array}{l}\text { Read the problem and combine with figure } 3.1 \text {, there will be the following summary: } \\
\text { Initially } \mathrm{t}=0 \text { hour, there is } 1 \text { cell. } \\
\text { After } \mathrm{t}=1 \text { hour, there are } 2 \text { cells. } \\
\text { After } \mathrm{t}=2 \text { hours, there are } 4 \text { cells } \ldots \\
\text { There are no additional conditions. And the topic requires finding: } \\
\text { a) Number of daughter cells after } \mathrm{n} \text { hours and after } 24 \text { hours. } \\
\text { b) When will there be } 1024 \text { cells? }\end{array}$ \\
\hline Is there a general formula for this problem? & $\begin{array}{l}\text { We need to find a function or an expression that represents the growth of unicellular } \\
\text { fungal cells. }\end{array}$ \\
\hline $\begin{array}{l}\text { What can we do with the data from the topic? } \\
\text { How do we come up with the required formula? }\end{array}$ & $\begin{array}{l}\text { We have the following argument: } \\
\text { When } t=0 \text { hour, there is } 1=2^{0} \text { cell. } \\
\text { After } t=1 \text { hour, there are } 2=2^{1} \text { cells. } \\
\text { After } t=2 \text { hours, there are } 4=2^{2} \text { cells. } \\
\text { After } t=3 \text { hours, there are } 8=2^{3} \text { cells. } \\
\text { After } t=4 \text { hours, there are } 16=2^{4} \text { cells. } \\
\text { After } t=5 \text { hours, there are } 32=2^{5} \text { cells... } \\
\text { Find the function in } t \text { to represent the number of unicellular yeast cells after } t \text { hours. }\end{array}$ \\
\hline $\begin{array}{l}\text { Please make your arguments and comment. Is } \\
\text { there anything special to you about the number of } \\
\text { cells? What is the relationship between time and } \\
\text { the number of cells? }\end{array}$ & $\begin{array}{l}\text { The number of cells is calculated according to the power of the base } 2 . \text { After the } \\
\text { argument, we find that the relationship between the time and the number of cells is } \\
N(t)=2^{t} \text {, this is also the general formula to find the number of cells after } t \text { hours. }\end{array}$ \\
\hline \multicolumn{2}{|l|}{ Step 2: Solve the math problem } \\
\hline $\begin{array}{l}\text { Is this problem strange or familiar? What kind of } \\
\text { thing is it? Have you seen it? How do you use } \\
\text { terms and data? Do you make full use of the given } \\
\text { assumptions and conditions? What formula, } \\
\text { theorem, or property can be used to solve that } \\
\text { problem? }\end{array}$ & $\begin{array}{l}\text { a) When } t=n \text { hours, replace } t=n \text { in the formula just found out, we will have } \\
N(n)=2^{n} \text {. } \\
\text { Then, } t=24 \text {, we have } N(24)=2^{24}=16777216 \text {. } \\
\text { b) When will we have } 1024 \text { daughter cells? } \\
\text { This problem is new and there is no way or solution suitable for the problem. } \\
\text { We can only solve it when we find the general formula for the number of cells after } t \\
\text { hours is } N(t)=2^{t} \text {. Conversely, we can only find the time to reach x cells when we } \\
\text { have the function } t=\log _{2} x \text {. After using all the facts for the problem and reasoning, } \\
\text { we have: } N(t)=1024=2^{t} \text {, find time } t, t=\log _{2} 1024=10 \text {. }\end{array}$ \\
\hline $\begin{array}{l}\text { What is the conclusion for the actual problem? Is } \\
\text { there any adjustment? }\end{array}$ & $\begin{array}{l}\text { a) After } n \text { hours, there will be } N(n)=2^{n} \text { daughter cells. After } 24 \text { hours, we will } \\
\text { have } N(24)=2^{24}=16777216 \text { daughter cells. } \\
\text { b) After } 10 \text { hours, there will be } 1024 \text { daughter cells. }\end{array}$ \\
\hline \multicolumn{2}{|l|}{ Step 3: Expand and exploit the actual problem } \\
\hline $\begin{array}{l}\text { Compare the results of the above arguments with } \\
N(t)=t^{2} \text {. Comment the comparison results } \\
\text { when changing exponent and radix together. }\end{array}$ & $\begin{array}{l}\text { Replace } t=6 \text { into the formula } N(t)=2^{t} \text {, then } N(t)=2^{6}=64 \\
\text { Substitute } t=6 \text { into the formula } N(t)=t^{2} \text {, then } N(t)=6^{2}=36 . \\
\text { We have: } N(t)=2^{6}=64>N(t)=6^{2}=36 \text {. } \\
\text { When the variable between the base and the exponent was changed, there was a } \\
\text { significant change. }\end{array}$ \\
\hline $\begin{array}{l}\text { Note: When a variable is exponential, even a } \\
\text { small change in the variable can cause a } \\
\text { significant change in the value of a function. }\end{array}$ & Listen attentively and absorb. \\
\hline
\end{tabular}


Table 2 Continued

\begin{tabular}{|c|c|}
\hline Propose the general problem of cell division. & $\begin{array}{l}\text { Based on the problem just solved, we can give the following general problem: } \\
\text { If we start with a cell under favorable growth conditions, then in an hour it will divide } \\
\text { into } \mathrm{n} \text { "daughter cells". Next, after an hour, each of these daughter cells will divide } \\
\text { into } \mathrm{n} \text { "daughter cells". } \\
\text { We have the following argument: } \\
\text { When } t=0 \text { cell division, there are } n^{0} \text { cells. } \\
\text { After } t=1 \text { cell division, there are } n^{1} \text { cells. } \\
\text { After } t=2 \text { cell division, there are } n^{2} \text { cells. } \\
\text { After } t=3 \text { cell division, there were } n^{3} \text { cells. } \\
\text { After } t=4 \text { cell division, there were } n^{4} \text { cells. } \\
\text { After } t=5 \text { cell division, there are } n^{5} \text { cells ... } \\
\text { The number of cells is calculated according to the power of the base } n \text {. Then the } \\
\text { number of cells after } t \text { hours will be } N(t)=n^{t} \text { and to find the time to reach } A \text { cells, } \\
\text { we use the function } t=\log _{n} A \text {. }\end{array}$ \\
\hline $\begin{array}{l}\text { Note: Cell division time can be calculated by a } \\
\text { number of times, phase, or time (days, hours, ...). } \\
\text { The most common number of } n \text { cells is } 2 \text { and } 4 \text {. }\end{array}$ & Listen attentively and absorb. \\
\hline
\end{tabular}

The following figure shows the duplication of unicellular yeast cells:

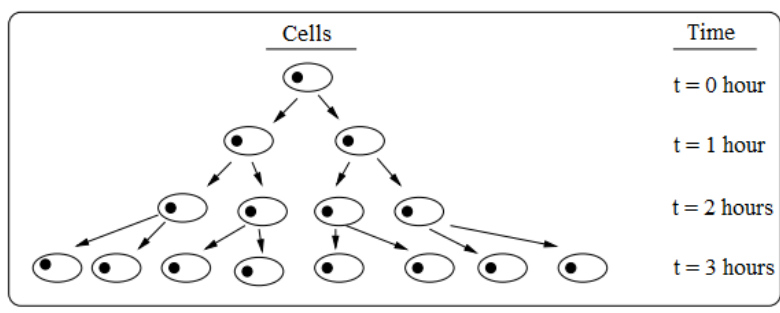

Figure 2. Process of the replication of yeast cells. [33]

With the above example, the work of setting up general formulas for the actual problem on the topic of exponential functions and logarithmic functions are performed in the activities in the transition from the real problem to the math problem. Students assign specific values to the problem so that the general formula can be established. Students then solve the math problem. Finally, students deepen their thinking to find general problems, similar problems, and new problems with the help of teachers. Thanks to such activities, students not only can practice and develop their ability to reason and to criticize but also to practice their problem-based learning competence.

Example 2. (Compound interest problem) $A$ person deposits VND 1 million into a bank at an annual interest rate of $7 \%$. We know that if the money is not withdrawn from the bank, every year, the interest will be entered into the original capital (it is called compound interest). How much money does the person receive after $n$ years $\left(n \in \mathbb{N}^{*}\right)$, if there is no withdrawal within this period and the interest rate does not change? When $n=5$ years, how much money will the person have? [34].

We guide students to solve the above example according to the teaching process of generalizing the actual problem on the topic of exponents and logarithmic functions oriented the development competence of problem-based learning in table 3 as follows: 
Table 3. Teaching the generalization of compound interest problem

\begin{tabular}{|c|c|}
\hline Teacher & Students \\
\hline \multicolumn{2}{|c|}{ Step 1: Convert from an actual problem to a math problem } \\
\hline $\begin{array}{l}\text { What facts and requirements does the } \\
\text { problem give us? Are there any conditions? }\end{array}$ & $\begin{array}{l}\text { The amount of invested capital is VND1 million with an interest rate of } 7 \% \text { annually. } \\
\text { Calculate the total amount after } \mathrm{n} \text { years. } \\
\text { Investing in the form of compound interest: interest will be added to the original capital } \\
\text { and the interest itself will continue to generate interest. }\end{array}$ \\
\hline Is there a general formula for this problem? & $\begin{array}{l}\text { Because it is the general number } n \text {, it cannot be found immediately but requires finding the } \\
\text { general formula. } \\
\text { We need to find a function or some expression that represents the growth of unicellular } \\
\text { fungal cells. }\end{array}$ \\
\hline $\begin{array}{l}\text { What can we do with the data and what we've } \\
\text { just learned from the problem? }\end{array}$ & $\begin{array}{l}\text { Perform the accrual in this way: interest will be added to the original capital and the } \\
\text { interest itself will continue to generate interest. }\end{array}$ \\
\hline $\begin{array}{l}\text { Make an argument and see if there is any } \\
\text { special thing or relationship between the } \\
\text { given facts? }\end{array}$ & 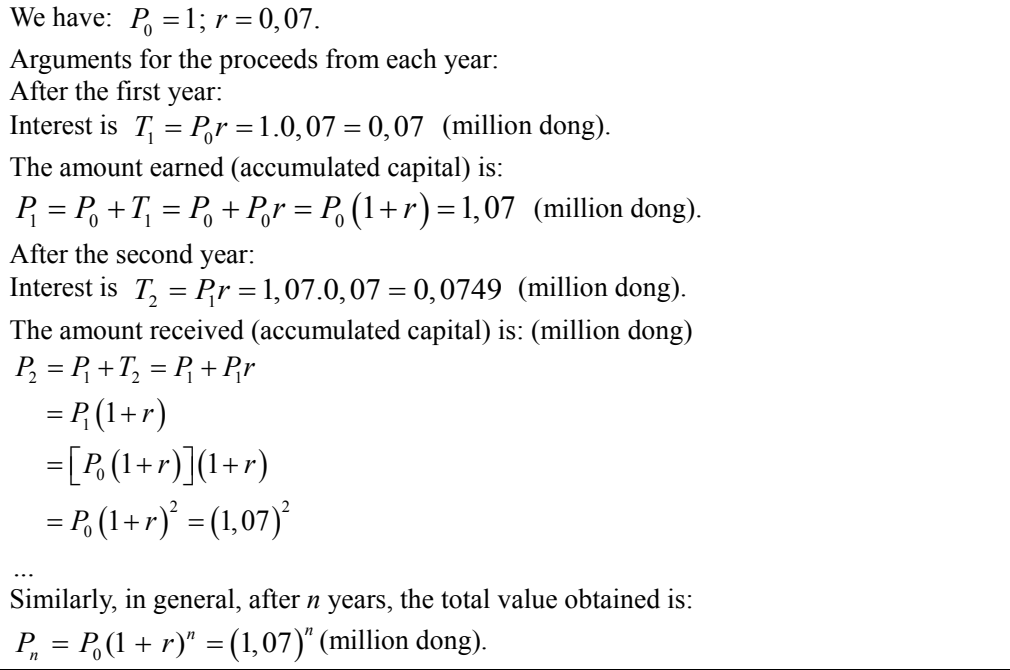 \\
\hline \multicolumn{2}{|l|}{ Step 2: Solve the math problem } \\
\hline $\begin{array}{l}\text { Is it possible to now calculate how much } \\
\text { money that person has earned? Calculate the } \\
\text { amount paid. }\end{array}$ & $\begin{array}{l}\text { After setting the above formula, we have: } \\
\text { After } n \text { years, the total achieved value is: } P_{n}=P_{0}(1+r)^{n}=(1,07)^{n} \text { (million dong). } \\
\text { Replace } n=5 \text { years, the total value obtained is: } \\
P_{5}=P_{0}(1+r)^{5}=(1,07)^{5}=1,402551731 \text { (million dong). }\end{array}$ \\
\hline $\begin{array}{l}\text { What is the conclusion for the actual } \\
\text { problem? Is there any adjustment? }\end{array}$ & $\begin{array}{l}\text { After } n \text { years, the total value achieved is: } P_{n}=P_{0}(1+r)^{n}=(1,07)^{n} \text { (million dong). } \\
\text { After } n=5 \text { years, the total value achieved is } 1,402551731 \text { (million dong) or } \\
\text { approximately } 1402600 \text { (million dong). }\end{array}$ \\
\hline \multicolumn{2}{|l|}{ Step 3: Expand and exploit the actual problem } \\
\hline $\begin{array}{l}\text { Please state the problem and general formula } \\
\text { for compound interest. }\end{array}$ & $\begin{array}{l}\text { Call the initial capital } P_{0} \text {. The investor wants the interest rate } r \text { per period as compound } \\
\text { interest. The investor invests money for } n \text { periods. We know that, at the end of each period, } \\
\text { the investor withdraws interest and only leaves the capital, calculate } P_{n} \text { which is the total } \\
\text { amount earned (including capital and interest) after } n \text { periods. } \\
\text { The interest earned after } n \text { periods is } P_{n}-P_{0} \text {. } \\
\text { Arguments for the proceeds each year: } \\
\text { After the first year: } \\
\text { The interest is } T_{1}=P_{0} r \text {. The amount received (accumulated capital) is: } \\
P_{1}=P_{0}+T_{1}=P_{0}+P_{0} r=P_{0}(1+r) \text {. } \\
\text { After the second year: } \\
\text { The interest is } T_{2}=P_{1} r \text {. The amount earned (accumulated capital) is: } \\
P_{2}=P_{1}+T_{2}=P_{1}+P_{1} r=P_{1}(1+r) \\
\quad=\left[P_{0}(1+r)\right](1+r)=P_{0}(1+r)^{2} \\
\ldots \\
\text { Similarly, in general, after } n \text { years, the total value obtained is: } \\
P_{n}=P_{0}(1+r)^{n} \text { (compound interest formula). }\end{array}$ \\
\hline
\end{tabular}


Table 3. Continued

\begin{tabular}{|l|l|}
\hline $\begin{array}{l}\text { For compound interest formula: } \\
+ \text { The time unit of each period can be a year, } \\
\text { quarter, month, or day. } \\
+ \text { Interest is expressed as a decimal. }\end{array}$ & Listen and absorb. \\
\hline $\begin{array}{l}\text { Please state the inverse problem for the } \\
\text { compound interest problem. }\end{array}$ & $\begin{array}{l}+ \text { Find time to get a certain amount. } \\
+ \text { Find interest. } \\
+ \text { Find the initial amount. }\end{array}$ \\
\hline
\end{tabular}

Here is an example to help students learn how to set up an exponential formula to solve math problems. At the same time, it is also used by the Textbook of Analysis 12 in Vietnam to form the exponential definition as well as the compounding formula for students. During the solving process, the formulation of formulas is done by answering the teachers' questions and requests. Through activities, students will gradually develop the ability to recognize, detect, and solve problems.

Example 3. (Continuous compound interest rate problem) An amount of \$ 5,000 is invested at an interest rate of $5 \%$ per annum. Form a formula for the sum of the money after $t$ years and how long does it take for the amount to double if interest is exercised on continuous compounding? [35]

We guide students to solve the above example according to the teaching process of generalizing the actual problem on the topic of exponents and logarithmic functions oriented the development competence of problem-based learning in table 4 as follows:

Table 4. Teaching the generalization of the continuous compounding problem

\begin{tabular}{|c|c|}
\hline Teacher & Students \\
\hline \multicolumn{2}{|c|}{ Step 1: Convert from an actual problem to a math problem } \\
\hline Summarize the problem and represent it with mathematical notation. & $\begin{array}{l}\text { Available factors: } P=5000 \$ ; r=0,05 \\
\text { Requirements: find a formula that calculates the sum of the } \\
\text { money earned after } t \text { years and how long it will take for the } \\
\text { amount to double. } \\
\text { Interest is calculated in the form of continuous compounding. }\end{array}$ \\
\hline $\begin{array}{l}\text { Is there a general formula for this problem? What is the form of } \\
\text { continuous compounding? What is special about this form, different } \\
\text { from the previous two forms of compounding? }\end{array}$ & $\begin{array}{l}\text { The compound interest formula can be used as it relates to the } \\
\text { compound interest form. } \\
\text { Students think about the problem posed. Consider setting up a } \\
\text { new recipe. }\end{array}$ \\
\hline What can we do with the data extracted from the topic? & $\begin{array}{l}\text { Based on the factors given, students reason to find an exponent } \\
\text { representing the money obtained in the form of continuous } \\
\text { compounding. }\end{array}$ \\
\hline $\begin{array}{l}\text { Suppose that if you deposit an initial capital } P_{0} \text { at the annual interest } \\
\text { rate } r \% \text { in the form of compound interest, then after } t \text { years of } \\
\text { deposit, what will be the return on both principal and interest? }\end{array}$ & $\begin{array}{l}\text { In the form of compound interest after } t \text { years, the proceeds are: } \\
P_{0}(1+r)^{t} \text {. }\end{array}$ \\
\hline $\begin{array}{l}\text { Suppose that we divide each year into } n \text { periods to calculate interest } \\
\text { and keep the annual interest rate } r \% \text {, then the interest per period will } \\
\text { be } \frac{r}{n} \text { and what is the amount after } \mathrm{t} \text { years? }\end{array}$ & $\begin{array}{l}\text { The interest rate per period is } \frac{r}{n} \text { and the amount earned after } t \\
\text { years (or after } n t \text { periods) is } P_{0}\left(1+\frac{r}{n}\right)^{n t} \text {. in the form of } \\
\text { compounding after } n t \text { periods. }\end{array}$ \\
\hline $\begin{array}{l}\text { When increasing the number of periods } n \text { in a year, what will be the } \\
\text { amount earned after } t \text { years? }\end{array}$ & $\begin{array}{l}\text { When increasing the number of periods } n \text { in a year, the amount } \\
\text { earned after } t \text { years also increases. }\end{array}$ \\
\hline $\begin{array}{l}\text { We see that the amount cannot grow indefinitely. The form of interest } \\
\text { calculation when } n \rightarrow+\infty \text { is called continuous compounding. Thus, } \\
\text { with the initial capital } \mathrm{P} \text { with the annual interest rate } r \text { in the form of } \\
\text { continuous compounding, it can be proved that after } t \text { years of deposit, } \\
\text { the amount of both the principal and the interest will be: } A(t)=P e^{r t} \text {. }\end{array}$ & Listen and receive ideas. \\
\hline \multicolumn{2}{|l|}{ Step 2: Solve the math problem } \\
\hline $\begin{array}{l}\text { Then, what is the formula for calculating the sum after } t \text { years of } \\
\text { investing an amount of } \$ 5000 \text { with } 5 \% \text { interest per year? }\end{array}$ & $\begin{array}{l}\text { With } P=5000 \$ ; r=0,05 \text {, we have the formula to calculate } \\
\text { the total amount after } t \text { years: } A(t)=5000 e^{0,05 t} \text {. }\end{array}$ \\
\hline
\end{tabular}


Table 4. Continued

\begin{tabular}{|c|c|}
\hline $\begin{array}{l}\text { Based on the above constant compound interest formula, find time to } \\
\text { double the amount? (During solving the problem, apply: } \\
\log _{a} b^{\alpha}=\alpha \log _{a} b \text { and } \log _{a} a=1 \text { ). }\end{array}$ & 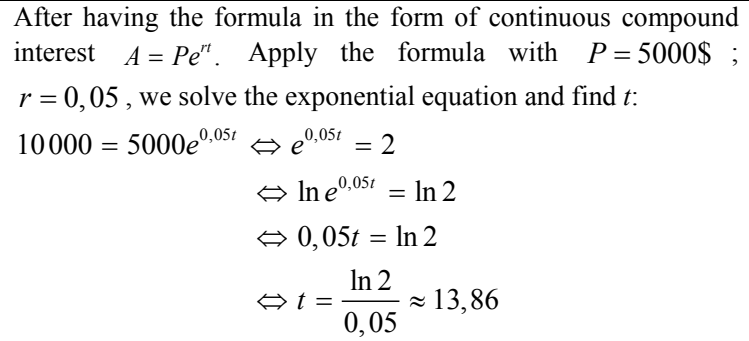 \\
\hline $\begin{array}{l}\text { What is the conclusion for the actual problem? Is there any } \\
\text { adjustment? }\end{array}$ & $\begin{array}{l}\text { The formula to look for is } A(t)=5000 e^{0,05 t} \text {. } \\
\text { That amount doubled after } 13.86 \text { years, or roughly } 13 \text { years, } 10 \\
\text { months, and } 7 \text { days. }\end{array}$ \\
\hline \multicolumn{2}{|l|}{ Step 3: Expand and exploit the actual problem } \\
\hline $\begin{array}{l}\text { General problem: With the initial capital } P \text { with the annual interest rate } \\
r \text { in the form of continuous compounding, it can be proved that after } t \\
\text { years of depositing, how much will the return on both capital and } \\
\text { interest be? (Provide the formula for continuous compound interest) }\end{array}$ & $\begin{array}{l}\text { The proceeds of both capital and interest will be: } A(t)=P e^{r t} \text {. } \\
\text { The formula } A(t)=P e^{r t} \text { is called the continuous compound } \\
\text { interest formula. }\end{array}$ \\
\hline $\begin{array}{l}\text { Besides the requirement to find the sum of money and find the time, } \\
\text { are there any other requirements for this problem? }\end{array}$ & $\begin{array}{l}\text { This type of problem also requires finding the interest rate or } \\
\text { finding the amount of capital. }\end{array}$ \\
\hline $\begin{array}{l}\text { Note: } \\
+ \text { Interest is expressed as a decimal. } \\
+ \text { It differs from the form of compounding that, in a year, there will be } \\
\text { forms of compounding annual interest such as monthly, weekly, daily, } \\
\text { or quarterly. }\end{array}$ & Listen and absorb \\
\hline
\end{tabular}

The above example can be used to form formula for the problem of continuous compound interest. Students and teachers work together to form a compound interest formula when $n \rightarrow+\infty$. Students will discover connections between formulas, along with differences between mathematical types.

Example 4. (Capital contribution problem) A person deposits the same amount in the bank every month as $V N D 3,000,000$ (at the beginning of each term), a 1-month term with an interest rate of $0.67 \%$ per month. After $t$ years, how much capital and interest will that person receive? [36]

We guide students to solve the above example according to the teaching process of generalizing the actual problem on the topic of exponents and logarithmic functions oriented the development competence of problem-based learning in table 5 as follows:

Table 5. Teaching the generalization of the capital contribution problem

\begin{tabular}{|l|l|}
\hline \multicolumn{1}{|c|}{ Teacher } & \multicolumn{1}{|c|}{ Students } \\
\hline \multicolumn{2}{|c|}{ Ste Convert from an actual problem to a math problem } \\
\hline Summarize the facts given. & $\begin{array}{l}\text { The capital contribution amount is } a=3 \text { million VND. The monthly interest rate is } r=0,0067 . \\
\text { What is the amount of capital and interest after n months? That is, look for } P_{n} .\end{array}$ \\
\hline $\begin{array}{l}\text { Is there a general formula for } \\
\text { this problem? }\end{array}$ & $\begin{array}{l}\text { We do not have a formula for the capital contribution problem yet, so let's set up a formula for this type } \\
\text { of math problem. }\end{array}$ \\
\hline $\begin{array}{l}\text { What can we do with the data } \\
\text { and what we just extracted from } \\
\text { the problem? So at the end of the } \\
\text { first month, how much money } \\
\text { does the investor get? }\end{array}$ & $\begin{array}{l}\text { At the end of the first month, the investor will have an amount: } \\
P_{1}=a+a r=a(1+r)=3(1+0,0067)=3,0201 .\end{array}$ \\
\hline & $\begin{array}{r}\text { At the beginning of the second month, the amount is: } \\
P_{1}+a=a(1+r)+a=a[1+(1+r)]=6,0201 .\end{array}$ \\
$\begin{array}{l}\text { At the beginning and end of the } \\
\text { second month, how much are the } \\
\text { investor's earnings? }\end{array}$ & $\begin{array}{r}\text { At the end of the second month, the amount is: } \\
P_{2}=P_{1}+P_{1} r=a+a(1+r)+[a+a(1+r)] r \\
=a\left[(1+r)^{2}+(1+r)\right] \approx 6,0604 .\end{array}$ \\
\end{tabular}


Table 5. Continued

\begin{tabular}{|c|c|}
\hline $\begin{array}{l}\text { Continue to execute the above } \\
\text { argument for } n \text { months. Find out } \\
\text { relationships between the given } \\
\text { facts. }\end{array}$ & 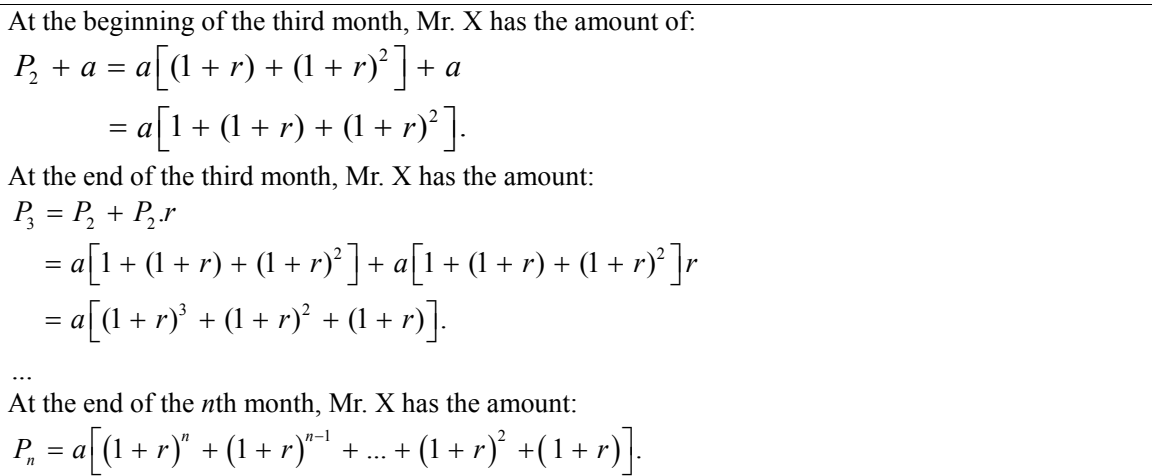 \\
\hline $\begin{array}{l}\text { Can you reduce the formula } \\
P_{n} \text { ? Do you notice anything } \\
\text { special about the expression in } \\
\text { square brackets? }\end{array}$ & $\begin{array}{l}\text { The terms in square brackets are the sequence of the exponentiation with the first term } u_{1}=1+r \text { and } \\
\text { the ratio } q=1+r \text {. The expression in square brackets is the sum of the first } n \text { terms of the exponential, } \\
\text { so we have: } S_{n}=u_{1} \frac{q^{n}-1}{q-1}=(1+r) \frac{(1+r)^{n}-1}{r} \text {. } \\
\text { So, we can reduce it as follows: } \\
\qquad P_{n}=a[\underbrace{(1+r)^{n}+(1+r)^{n-1}+\ldots+(1+r)^{2}+(1+r)}_{S_{n}}] \\
\Leftrightarrow P_{n}=a(1+r) \frac{(1+r)^{n}-1}{r} .\end{array}$ \\
\hline \multicolumn{2}{|l|}{ Step 2: Solve the math problem } \\
\hline $\begin{array}{l}\text { Using all the given assumptions } \\
\text { and conditions, work on solving } \\
\text { the problem. We use the } \\
\text { argument with the unit of time } \\
\text { which is months, so what if we } \\
\text { are asked to find the sum after } t \\
\text { years? }\end{array}$ & $\begin{array}{l}\text { After } t \text { years, ie } n=12 t \text { months, replace } n=12 t \text { and other data into the new formula, we have: } \\
\begin{aligned} P_{12 t}=3(1+0,0067) \frac{(1+0,0067)^{12 t}-1}{0,0067} \\
\quad=\frac{30201\left[(1+0,0067)^{12 t}-1\right]}{67} \\
\quad \approx 450,76\left[(1+0,0067)^{12 t}-1\right] .\end{aligned}\end{array}$ \\
\hline $\begin{array}{l}\text { What is the conclusion for the } \\
\text { actual problem? Is there any } \\
\text { adjustment? }\end{array}$ & $\begin{array}{l}\text { After } t \text { years, that person receives the principal and interest: } \\
P_{12 t} \approx 450,76\left[(1+0,0067)^{12 t}-1\right] \text { million dong. }\end{array}$ \\
\hline \multicolumn{2}{|c|}{ Step 3: Expand and exploit the actual problem } \\
\hline $\begin{array}{l}\text { Give a general description of the } \\
\text { installment problem and its } \\
\text { formula. }\end{array}$ & $\begin{array}{l}\text { A person deposits the same amount in the bank monthly as } a \text { dong (at the beginning of each term), for } \\
\text { a } 1 \text {-month term with an interest rate of } r \% \text { per month. What is the amount of capital and interest after } \\
\text { n months? } \\
\text { With the same argument as in step } 1 \text { and generalizing the formula found, we have: After } n \text { months, he } \\
\text { receives the capital and interest: } P_{n}=a(1+r) \frac{(1+r)^{n}-1}{r} \text {. }\end{array}$ \\
\hline $\begin{array}{l}\text { In addition to the requirement to } \\
\text { find the amount after a certain } \\
\text { time, what are the other } \\
\text { requirements? }\end{array}$ & $\begin{array}{l}\text { + Find time to contribute capital. } \\
+ \text { Find interest. } \\
\text { + Find the amount of recurring installment. }\end{array}$ \\
\hline
\end{tabular}

The formula for the monthly capital contribution problem is established through the argument about monthly accrual: contributing capital at the beginning of the month, making interest at the end of the month, arguing continuously until finding the final formula in the transition step from an actual problem to a math problem. Through it, students are trained in skills such as: using mathematical language, methods of inductive mathematics, logical reasoning, problem discovery (discovering the relationship between numbers in the amount expression at the end of the month), relating to old knowledge.

Thus, through this example, we see that setting up the general formula for the actual problem in step 1 is converting the actual problem into the math problem. Specifically, students need to identify given factors, exploit data, perform math, and find out the special connections and relationships between them to create a general formula for the problem. Next, students apply the formula just established to solve the problem. Finally, the formula will be repeated by the teacher in step 3, and students will be working with new problems. Through these steps, in addition to formulating formulas, practicing math solving skills, students are also trained in problem-based learning competence, logical reasoning, 
computation, and method of mathematical induction.

\subsection{Methodology}

\subsubsection{Purpose, Requirements, and Duties of the Pedagogical Experiment}

The purpose of our pedagogical experiment is to test the feasibility and effectiveness of fostering problem-based learning competence through generalizing the actual problem on the topic of exponential and logarithmic functions. The pedagogical experiment must ensure objectivity and science and it must be suitable for students and actual teaching situation and conditions. Teachers must compile lesson plans and conduct the proposed pedagogical experiment, know how to collect, process, analyze, and evaluate experimental results to verify the feasibility and effectiveness of the proposed pedagogical experiment.

\subsubsection{Content of pedagogical experiment}

The experimental contents are the following specific contents:

- Carrying out teaching in the experimental class according to the lesson "Practice exercises, chapter II: Exponentiation functions, exponential functions and Logarithmic functions" of Advanced 12th-grade Calculus of Vietnam according to the teaching process of generalizing practical problems on the subject of exponential functions, logarithmic functions.

- Experimental lessons are exercises with the content of Chapter II "Exponentiation functions, exponential functions, and logarithmic functions".

- After the experiment, conduct the test and assessment of the experimental class and the control class in the form of an essay; analyze the evaluation results of the experimental class and the control class to check the feasibility and effectiveness of the experiment.

\subsubsection{Experimental Objects}

We consulted 47 high school teachers in Ho Chi Minh City, Vietnam in a questionnaire survey: "In your opinion, is it important to develop problem-based learning competence on the topic of exponents and logarithms for students?". We obtained the results in table 6.

The data table shows that the majority of teachers believe that teaching to develop problem-based learning competence on the topic of exponentials and logarithms for students is very important $(63.83 \%)$ or important $(25.53 \%)$. This result shows that teachers appreciate the importance of developing problem-based learning competence on the topic of exponentials and logarithms for students in teaching.

Next, we conduct experiments at Nguyen An Ninh High School (District 10, Ho Chi Minh City, Vietnam) according to the advanced study program in Vietnam for the 2020-2021 school year.

- Experimental class 12A9 includes 45 students. Math teacher: Nguyen Thi Ly.

- Control class 12A13 includes 44 students. Math teacher: Nguyen Thi Ly.

We designed lesson plans and implemented teaching content "Practice exercises in chapter II" for both classes. For the experimental class, the teacher will teach according to lesson plans on practical problems oriented to foster problem-based learning competence. For the control class, the teacher will teach according to the normal program distribution. Practical problems must ensure the following:

- Define clearly key knowledge, skills to be achieved.

- Appropriate in terms of time and general knowledge of students.

- Activities in the teaching process must help students foster their problem-based learning competence through practical problems.

\subsubsection{Process of Pedagogical Experiment}

- Investigate and evaluate the learning situation of students in experimental and control classes.

- Prepare documents and compile experimental lesson plans according to the teaching process that generalizes the actual problem on the topic of exponential and logarithmic functions.

- Teachers give lessons according to the compiled lesson plan.

- After the teaching is completed, the teacher gives the experimental class and the control class a 45 -minute test.

- Collect, analyze, and evaluate test results of experimental and control classes.

Table 6. Teacher opinions on teaching to develop problem-based learning competence on the topic of exponential functions and logarithmic functions for students

\begin{tabular}{|c|c|c|c|c|c|c|c|}
\hline \multicolumn{2}{|c|}{ Not important } & \multicolumn{2}{c|}{ Less important } & \multicolumn{2}{c|}{ Important } & \multicolumn{2}{c|}{ Very important } \\
\hline $\begin{array}{c}\text { Number of } \\
\text { people }\end{array}$ & $\%$ & $\begin{array}{c}\text { Number of } \\
\text { people }\end{array}$ & $\%$ & $\begin{array}{c}\text { Number of } \\
\text { people }\end{array}$ & $\%$ & $\begin{array}{c}\text { Number of } \\
\text { people }\end{array}$ & $\%$ \\
\hline 0 & 0 & 5 & 10,64 & 12 & 25,53 & 30 & 63,83 \\
\hline
\end{tabular}




\subsubsection{Methods of Experimental Evaluation}

In the thesis, we use the following experimental evaluation methods:

- Classroom observations: to receive students' feedback on lessons about excitement, positive attitude, cognitive level, and applicability.

- Interview: We use the method of interviewing by talking with students to clarify information about the level of interest that is difficult to determine through observation. We interviewed teachers to get the teacher's assessment and comments on students' interest and perception in the experiment.

- Essay test: aims to assess students' ability to acquire knowledge through the lessons. Test the individual knowledge of the experimental class and the control class through the self-essay test after the experiment. Test content is based on the lesson plan's goals and we pay special attention to exercises to evaluate the effectiveness of students' use of problem-based learning competence. Scores of the tests are scored on a 10-point scale.

- Mathematical statistics method: After marking students' tests (rounded to one decimal), the test score data will be collected and processed using SPSS Statistics software. In which, we calculate the characteristic parameters of the statistics based on the following formulas:

Average score: $\bar{X}=\frac{1}{n} \sum_{i=1}^{k} n_{i} X_{i}$

Variance: $S^{2}=\frac{1}{n-1} \sum_{i=1}^{k} n_{i}\left(X_{i}-\bar{X}\right)^{2}$

Standard deviation: $S=\sqrt{\frac{1}{n-1} \sum_{i=1}^{k} n_{i}\left(X_{i}-\bar{X}\right)^{2}}$

In which, $\bar{X}$ is the average score; $X_{i}$ is the score achieved; $n_{i}$ is the number of papers (the number of students) achieving a corresponding $X_{i}$ score in each test; $k$ is the number of different groups of points; $n$ is the sample size (total number of students tested).

Standard deviation indicates the dispersion of the score data around the mean. The lower the $S$-index, the less dispersion around the mean and the higher the concentration around the mean.

+ Test hypotheses to compare two mean values of two independent samples by SPSS Statistical software.

\subsubsection{Analyze Before Conducting the Experiment}

We surveyed the math performance of two classes through their homeroom teacher and class subject teacher and we obtained the most recent test scores for both classes for the 2020-2021 school year. (See Table 7).

And we have figure 3 comparing the results of the most recent tests of students before conducting a pedagogical experiment between experimental class and control class based on Table 7 as follows:

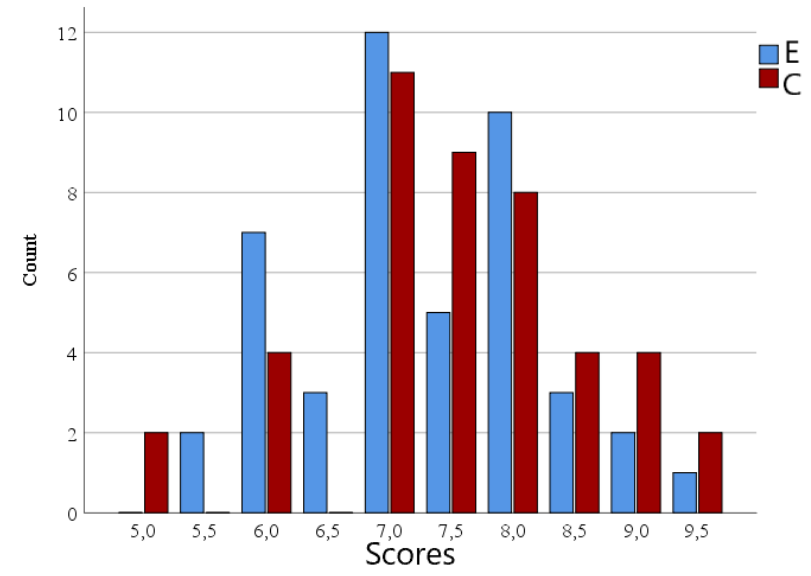

Figure 3. Bar chart comparing scores of Math tests of experimental and control classes (pre-experimental) in SPSS

From Figure 3, we see that the height difference of the columns is not much, showing that the score frequencies of the two classes are nearly the same. The distribution of scores for the two classes is nearly equal.

Table 7. Table of the frequency distribution of scores on the Math test of experimental and control classes (pre-experimental) in SPSS

\begin{tabular}{|c|c|c|c|c|c|c|c|c|c|c|c|c|}
\hline & \multicolumn{10}{|c|}{ Scores } & \multirow{2}{*}{ Total } \\
\hline & & 5,0 & 5,5 & 6,0 & 6,5 & 7,0 & 7,5 & 8,0 & 8,5 & 9,0 & 9,5 & \\
\hline \multirow{2}{*}{ Class } & Experimental & 0 & 2 & 7 & 3 & 12 & 5 & 10 & 3 & 2 & 1 & 45 \\
\hline & Control & 2 & 0 & 4 & 0 & 11 & 9 & 8 & 4 & 4 & 2 & 44 \\
\hline \multicolumn{2}{|r|}{ Total } & 2 & 2 & 11 & 3 & 23 & 14 & 18 & 7 & 6 & 3 & 89 \\
\hline
\end{tabular}


Besides, from the data in Table 7, we obtain the typical parameters of the statistics as in Table 8 .

Table 8. Table of typical parameters of Mathematics test scores for experimental and control classes (pre-experimental) in SPSS

\begin{tabular}{|c|c|c|c|c|}
\hline \multicolumn{2}{|c|}{} & \multicolumn{3}{c|}{ scores } \\
\cline { 2 - 5 } \multicolumn{2}{|c|}{} & Mean & Variance & Standard Deviation \\
\hline \multirow{3}{*}{ Class } & Experimental & 7,27 &, 94 &, 97 \\
\cline { 2 - 5 } & Control & 7,53 & 1,10 & 1,05 \\
\hline
\end{tabular}

From the results for Table 8 test scores, we get:

The average grade of the two classes is: $\overline{X_{T N}}=7,27 ; \overline{X_{D C}}=7,53$.

Variance: $S_{T N}^{2}=0,94 ; S_{D C}^{2}=1,10$

Comment: the difference between the mean and variance of the two classes is not large. We can say that the scores of the two classes are nearly equal.

To accurately assess the equivalent or difference between the average scores of the two classes that we experimented with, we test the hypothesis $H_{0}$ : "The average score of the latest Math test of the experimental class and the control class was equivalent", with a significant level $\alpha=0,05$ by T-test table (table 9).

From Table 9, we have the following results:

- According to the Levene test, we have a value of Sig $=0.05$, so the variance of the two classes is equivalent, using the results of the Independent-samples T-test corresponding to the case where the variance of two classes is equal.

- According to the Independent-samples T-test, we have Sig $=0.05$, so we accept the hypothesis $\mathrm{H} 0$, the average score of the closest Math test of the experimental class and the control class are equivalent.

From the above results, we can confirm that the
Mathematics skills of the two classes are similar.

\subsubsection{Analyze Experimental Results}

We conducted experimental teaching while following up, observing the progress, and interviewing to give some comments as follows:

- Before experimenting, students in both classes have not had much access to the practical problem on the topic of exponents and logarithms, so even though they are interested in it, students are still afraid and have not solved the actual problem yet.

During the experiment, we found:

+ Experimental class atmosphere is positive; students are interested in practical problems so they voluntarily participate in activities; high teaching efficiency.

+ Compared with the control class, students in the experimental class operate and learn by more activities, acquire knowledge more effectively.

- After experimenting, students also have some changes as follows:

+ Students in the experimental class no longer have difficulty solving real problems, know how to make the most of hypotheses with many questions; They consciously check the facts of the problem as well as whether the results match the reality or not.

+ Students in the experimental class have a better grasp of the contents of practical problems than the control class, from which they can solve problems quickly and begin to be more confident with their abilities; they actively learn from real-life problems more than before.

Through the above comments and assessments, we believe that the proposed experiment is initially effective in teaching. However, to ensure objectivity about the effectiveness of the experiment, we conduct quantitative analysis and evaluation by Mathematical statistics through SPSS software.

Table 9. Average T-test checklist of Mathematics test scores of experimental and control classes (pre-experimental) in SPSS

\begin{tabular}{|c|c|c|c|c|c|c|c|c|c|c|}
\hline \multicolumn{11}{|c|}{ Independent Samples Test } \\
\hline & & \multicolumn{2}{|c|}{$\begin{array}{l}\text { Levene's Test for } \\
\text { Equality of Variances }\end{array}$} & \multicolumn{7}{|c|}{ t-test for Equality of Means } \\
\hline & & \multirow{2}{*}{$\mathrm{F}$} & \multirow{2}{*}{ Sig. } & \multirow{2}{*}{$\mathrm{T}$} & \multirow{2}{*}{ df } & \multirow{2}{*}{$\begin{array}{c}\text { Sig. } \\
\text { (2-tailed) }\end{array}$} & \multirow{2}{*}{$\begin{array}{c}\text { Mean } \\
\text { Difference }\end{array}$} & \multirow{2}{*}{$\begin{array}{l}\text { Std. Error } \\
\text { Difference }\end{array}$} & \multicolumn{2}{|c|}{$\begin{array}{l}\text { 95\% Confidence Interval of the } \\
\text { Difference }\end{array}$} \\
\hline & & & & & & & & & Lower & Upper \\
\hline \multirow[t]{2}{*}{ Scores } & $\begin{array}{c}\text { Equal } \\
\text { variances } \\
\text { assumed }\end{array}$ & 0,002 & 0,968 & $-1,251$ & 87 & 0,214 & $-0,26742$ & 0,21383 & $-0,69244$ & 0,15759 \\
\hline & $\begin{array}{c}\text { Equal } \\
\text { variances not } \\
\text { assumed }\end{array}$ & & & $-1,250$ & 86,126 & 0,215 & $-0,26742$ & 0,21402 & $-0,69288$ & 0,15803 \\
\hline
\end{tabular}


through Teaching the Generalization of Practical Problems on the Topic of Exponential and Logarithmic Functions

Table 10. Table of the frequency distribution of test scores for experimental and control classes (post-experimental) in SPSS

\begin{tabular}{|c|c|c|c|c|c|c|c|c|c|c|c|c|}
\hline & & \multicolumn{10}{|c|}{ scores } & \multirow{2}{*}{ Tota } \\
\hline & & 5,5 & 6,0 & 6,5 & 7,0 & 7,5 & 8,0 & 8,5 & 9,0 & 9,5 & 10,0 & \\
\hline \multirow{2}{*}{ Class } & Experimental & 0 & 3 & 1 & 7 & 6 & 10 & 6 & 5 & 5 & 2 & 45 \\
\hline & Control & 4 & 6 & 5 & 5 & 3 & 8 & 2 & 6 & 4 & 1 & 44 \\
\hline \multicolumn{2}{|r|}{ Total } & 4 & 9 & 6 & 12 & 9 & 18 & 8 & 11 & 9 & 3 & 89 \\
\hline
\end{tabular}

To test the feasibility and evaluate the effectiveness of the experiment, we gave students in the experimental class and the control class a 45-minute test (essay exam). Quantitative analysis is based on the test results. First of all, we create table 10 .

From the data in Table 10, we have figure 4 comparing the scores of the two classes:

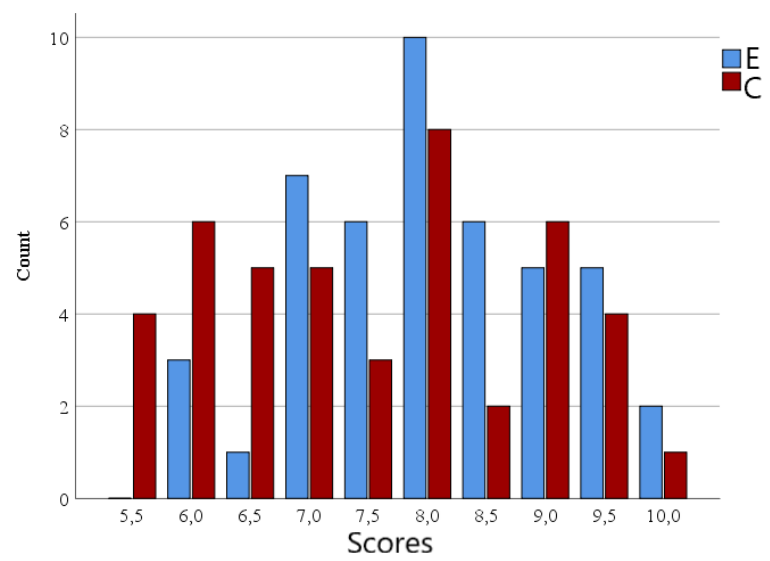

Figure 4. Bar chart comparing test scores of experimental and control classes (after the experiment) in SPSS

From Figure 4, we can see that there are differences in the height of the grade columns and the distribution of scores of the two classes. The scores of the experimental classes range from 6 to 10 points and most are 7-9.5 points. The distribution of scores of the control class is from 5.5 to 10 points and a large number is from 5.5 to 8 points. Besides, we also obtain the typical parameters of the statistics as table 11:

Table 11. Table of characteristic parameters of the statistics on the test scores of experimental and control classes (post-experimental) in SPSS

\begin{tabular}{|c|c|c|c|c|}
\hline \multicolumn{2}{|c|}{} & \multicolumn{3}{c|}{ scores } \\
\cline { 3 - 5 } \multicolumn{2}{|c|}{} & Mean & Variance & $\begin{array}{c}\text { Standard } \\
\text { Deviation }\end{array}$ \\
\hline \multirow{2}{*}{ class } & Experimental & 8,04 & 1,10 & 1,05 \\
\cline { 2 - 5 } & Control & 7,52 & 1,76 & 1,32 \\
\hline
\end{tabular}

Reading the above test result data, we have:

The average grade of the two classes is: $\overline{X_{T N}}=8,04 ; \overline{X_{D C}}=7,52$.

Variance: $S_{T N}^{2}=1,10 ; S_{D C}^{2}=1,76$.

Comment: the mean and variance of the two classes have a big difference. The GPA of the experimental class is higher; The standard deviation and variance are lower, so the concentration around the mean is higher than that of the control. We can say that the experimental class's scores are higher than those of the control class.

To accurately assess the difference (or the high, low) between the average points of the two classes, we test the average between the two classes, with a significance level of $\alpha=0,05$ through Table 12 with the following two assumptions:

Hypothesis $H_{0}$ : "The average score of the experimental class and the control class are similar".

$H_{l}$ : "The average score of the experimental class is higher than that of the control class".

Table 12. Average T-test checklist of test scores of experimental and control classes (post-experimental) in SPSS

\begin{tabular}{|c|c|c|c|c|c|c|c|c|c|c|}
\hline \multicolumn{11}{|c|}{ Independent Samples Test } \\
\hline & & \multicolumn{2}{|c|}{$\begin{array}{c}\text { Levene's Test for } \\
\text { Equality of Variances }\end{array}$} & \multicolumn{7}{|c|}{ t-test for Equality of Means } \\
\hline & & \multirow[t]{2}{*}{$\mathrm{F}$} & \multirow[t]{2}{*}{ Sig. } & \multirow[t]{2}{*}{$\mathrm{t}$} & \multirow[t]{2}{*}{$\mathrm{df}$} & \multirow{2}{*}{$\begin{array}{c}\text { Sig. } \\
\text { (2-tailed) }\end{array}$} & \multirow{2}{*}{$\begin{array}{c}\text { Mean } \\
\text { Difference }\end{array}$} & \multirow{2}{*}{$\begin{array}{l}\text { Std. Error } \\
\text { Difference }\end{array}$} & \multicolumn{2}{|c|}{$\begin{array}{l}\text { 95\% Confidence Interval of the } \\
\text { Difference }\end{array}$} \\
\hline & & & & & & & & & Lower & Upper \\
\hline \multirow{2}{*}{ Score } & $\begin{array}{c}\text { Equal } \\
\text { variances } \\
\text { assumed }\end{array}$ & 5,060 &, 027 & 2,062 & 87 & ,042 &, 52172 & ,25300 &, 01886 & 1,02458 \\
\hline & $\begin{array}{c}\text { Equal } \\
\text { variances not } \\
\text { assumed }\end{array}$ & & & 2,057 & 81,824 & ,043 &, 52172 & ,25366 &, 01709 & 1,02634 \\
\hline
\end{tabular}


From the result sheet, we have:

- According to the Levene test, we have the value $\mathrm{Sig}=$ 0.05 , so the variance of the two classes is not equal, using the results of the Independent-samples T-test corresponding to the case where the variance of the two samples is not equal.

- According to the Independent-samples T-test, we have Sig $=5$, so we reject hypothesis $\mathrm{H} 0$, accept hypothesis H1. So the average score of the experimental class is $5 \%$ higher than that of the control class.

Thus, by the method of testing between classes with equivalent learning, the results show that the experimental class, after being taught according to the teaching process of generalizing the actual problem on the topic of the exponential and logarithmic function, the test and the GPA is higher than those of the control class. It can be seen that the experiment applied to the experimental class is completely feasible and effective in teaching.

\section{Conclusions}

From the results in the process of conducting pedagogical experiments, it shows that the implementation of fostering problem-based learning competence through teaching the generalization of practical problems on the topic of the exponential function and logarithmic function is feasible and effective. We answered four questions in introduction section. First is to compare problem detection and solving teaching methods with teaching towards developing problem-based learning competence. Second is to give a process of teaching generalizing practical problems on the topic of exponents and logarithms. Third is to give some illustrative examples of problem-based learning competence through teaching about generalizing the real problem on the topic of exponents and logarithmic functions. Fourth is to prove the effectiveness of teaching about generalizing the real problem on the topic of exponents and logarithmic functions. Attention is paid to pedagogical activities and especially the pedagogical experimental organization process is focused. The experimental results are processed using SPSS software. However, the paper has not mentioned problem-based learning competence in the direction of applying information technology in teaching practical problems on the topic of exponent and logarithmic functions. We look forward to your interest and discovery in this research direction.

\section{Acknowledgments}

We would like to thank Mr. Nguyen Viet Duong for reading and commenting to complete the manuscript.

\section{REFERENCES}

[1] J. P. Deborah, "A problem-posing intervention in the development of problem-solving competence of underachieving, middle-year students," Queensland University of Technology, Kelvin Grove Campus, Brisbane: the degree of Doctor of Philosophy, 2009.

[2] A. Kretzschmar and H. Süß, "A study on the training of complex problem-solving competence.," J. Dyn. Decis. Mak., vol. 1, no. 1, pp. 1-15, 2015, doi: $10.11588 / \mathrm{jddm} .2015 .1 .15455$.

[3] M. Syaifuddin, "Increasing problem-solving competence through problem-based learning model and scientific approach," Pertanika J. Soc. Sci. Humanit., vol. 25, no. August, pp. 121-130, 2017.

[4] T.T.H. Hoang, "Evaluation of students' ability to solve problems in teaching 'Laws of conservation' Physics 10," Hanoi National University: Thesis Master of Physics Pedagogy, 2015.

[5] X.T Ha, "Teaching mathematics in high schools in the direction of developing the ability to solve practical problems through the exploitation and use of real situations," Vietnam Institute of Educational Science, Hanoi: Doctoral thesis, 2017.

[6] D. H. Nguyen, "Developing computing capacity for students in teaching 'Power functions, exponential functions, and logarithms' (Calculus grade 12)," Journal of Education, special vol., pp. 194-196, 2019.

[7] R. Caldwell, "Are HR business partner competency models effective?," Appl. HRM Res., vol. 12, no. 1, pp. 40-58, 2010.

[8] F. E. Weinert, "Vergleichende Leistungsmessung in Schulen - eineumstrittene Selbstverstondlichkeit," Leistungsmessung Schulen, Weinheim und Basejl Beltz Verlag, vol. 25, pp. 1732, 2001, Accessed: Jul. 12, 2020. [Online]. Available: https://pure.mpg.de/pubman/faces/ViewItemOverviewPage. jsp?itemId=item_727844.

[9] OECD, Definition and selection of competencies (DeSeCo): theoretical and conceptual foundations: strategy paper. 2002.

[10] D. Tremblay, "The Competency-Based Approach: Helping learners become autonomous," Adult Educ. - A Lifelong Journey, vol. 5, 2002.

[11] A. Maaleki, The ARZESH competency model: Appraisal \& development manager's competency model. Lambert Academic Publishing, 2018.

[12] National Council for directing the compilation of Vietnamese Encyclopedia, Vietnamese Encyclopedia, volume 3. Hanoi Encyclopedia Publishing House, 2003.

[13] Institute of Linguistics, Hoang Phe (editor), Vietnamese Dictionary. Dictionary Center, Danang Publishing House, 2005.

[14] Đ. P. Pham, Minh Hac., Le, Some personality research issues. Hanoi: National Political Publishing House, 2004.

[15] T. H. Dang, "Competence and education according to the competency-based approach," Journal of Educational Management, vol. 43, pp. 18-26, 2012. 
through Teaching the Generalization of Practical Problems on the Topic of Exponential and Logarithmic Functions

[16] H. B. Hoang, "Competence and capacity assessment," Journal of Science, Ho Chi Minh City University of Pedagogy, vol. 6, no. 71, pp. 21-31, 2015.

[17] Ministry of Education and Training of Vietnam, "Comprehensive General Education Program Workshop Document in the New General Education Program." Documents for internal circulation, Hanoi, p. 5, 2015.

[18] Vietnam Ministry of Education and Training, "General Education Program - general program." 2018.

[19] H. T. Nguyen, "Teaching Mathematics through experiential activities to form and develop math competencies for junior high school students," Journal of Education, vol. No. 412, pp. 27-30, 2017

[20] M. Niss, "Mathematical Competencies and the Learning of Mathematics : the Danish Kom Project," in Proceedings of the 3rd Mediterranean Conference on Mathematical Education, 2003, pp. 115-124.

[21] M. Blomhøj and T. H. Jensen, "What's all the Fuss about Competencies?," in Modelling and Applications in Mathematics Education, New ICMI S., vol. 10, Blum W., Galbraith P.L., Henn HW., Niss M., Ed. Boston, MA: Springer, 2007, pp. 45-56.

[22] PISA, "Field Trial Problem Solving Framework," 2010. https://scholar.google.com/scholar?hl=vi\&as sdt=0\%2C5\& $\mathrm{q}=$ Field + Trial + Problem + Solving + Framework. $\&$ btnG $=$ (accessed Jul. 11, 2020).

[23] G.T. Nguyen, Thi Hong Hai., Nguyen, "Examining and evaluating students' ability to solve problems in teaching 'The Fundamental Principles of Marxism-Leninism' (Philosophy section) at Thai Nguyen College of Education today, "Journal of Education, special vol., pp. 199-201, 2016.

[24] Rajkumar R., Hema G., "Factors Affecting Mathematical Problem Solving Competence of Undergraduate Students in Facing Competitive Examinations," IMPACT Int. J. Res. Humanit. Arts Lit. (IMPACT IJRHAL), vol. 7, no. 2, pp. 319-328, 2019, [Online]. Available: www.impactjournals.u s.
[25] T. L. P. Nguyen, "Proposed structure and assessment standards of problem-solving capacity in the New High School Education Program," Journal of Educational Science, vol. 111, 2014.

[26] V. H. et al Nguyen, "Topic 7 Teaching according to the development of student capacity in junior high schools," Thai Nguyen, 2017

[27] B. K. Nguyen, Teaching Methods of Mathematics. Pedagogical University Publishing House, 2009.

[28] V. T. Le, Teaching Methods for Mathematics in High School. Ho Chi Minh City University of Education, 2005.

[29] M. Schröder, "Competence-oriented study programmes," FIBAA, no. June, 2015.

[30] Daniel Mansfield, "Is mathematics real? That viral TikTok video raises a legitimate question," Australia's Science Channel, 2020. https://australiascience.tv/is-mathematics-re al-that-viral-tiktok-video-raises-a-legitimate-question/ (accessed Sep. 12, 2020)

[31] G. Polya, Mathematical Discovery: On understanding, learning, and teaching problem solving, Combined E. Canada: John Wiley \& Sons, Inc, 1981.

[32] T. Wang and J. Cai, “Chinese (Mainland) teachers' views of effective mathematics teaching and learning," $Z D M$ - Int. J. Math. Educ., vol. 39, no. 4, pp. 287-300, Jul. 2007, DOI: $10.1007 / \mathrm{s} 11858-007-0030-7$.

[33] D. H. Collingwood, K. David Prince, and M. M. Conroy, Precalculus. 2011.

[34] Vietnam Ministry of Education and Training, Calculus 12, Advanced Calculus 12. Vietnam Education Publishing House, 2015.

[35] W. James, S., Lothar, R. \& Saleem, Precalculus: Mathematics for Calculus, 6th ed. Florence, KY, United States: Cengage Learning, Inc, 2011.

[36] L. P. et al Hua, Train skills in solving practical multiple-choice problems. Thanh Hoa Publishing House, 2017. 